\title{
AHP ve VIKOR Yöntemleri Kullanılarak BİST'te İșlem Gören Dokuma, Giyim Eşyası ve Deri İşletmelerinin Finansal Performans Analizi
}

\section{Financial Performance Analysis of Weaving, Clothing and Leather Businesses Traded in BíST using AHP and VIKOR Methods}

Muhammet Sait Işsıldak a,*

${ }^{\text {a }}$ Dr. Öğretim Üyesi, Tokat Gaziosmanpaşa Üniversitesi Zile Meslek Yüksekokulu 60400, Zile / Tokat / Türkiye. ORCID: 0000-0001-5715-7090

\begin{tabular}{l} 
MAKALE BİLGİSİ \\
\hline Makale Geçmişi: \\
Başvuru tarihi: 01 Ocak 2020 \\
Düzeltme tarihi: 18 Nisan 2020 \\
Kabul tarihi: 02 Mayıs 2020 \\
\hline Anahtar Kelimeler: \\
AHP \\
VİKOR \\
Performans değerlendirme \\
Dokuma \\
Giyim \\
Deri sektörü
\end{tabular}

A R T I C L E I N F O

\section{Article history:}

Received 01 January 2020

Received in revised form 18 April 2020

Accepted 02 May 2020

Keywords:
AHP
VIKOOR
Performance evaluation
Weaving
Clothing
Leather sector

ÖZ

$\mathrm{Bu}$ çalışmada, 2014-2017 yılları arasında BIST'te işlem gören tekstil, hazır giyim ve deri işletmelerinin finansal performans analizi, çok kriterli karar verme yöntemleri olan AHP ve VİKOR yöntemleri kullanılarak gerçekleştirilmiştir. Finansal performans analizinde kullanılan kriter ölçütleri finansal oranlardır. Çalıșmada ilk olarak mali oranların AHP yöntemi ile ağırlıklandırılması ve sıralanması yapılmıştır. Satış karlılık oranı birinci, stok bağımlılık oranı son sırada yer almıştır. İkinci aşamada, bu işletmelerin finansal performansları, stratejik ağırlık ve farklı seviyelerdeki grup faydaları VİKOR yöntemine göre sıralanmıştır. Sonuç olarak, SNPAM'ın yaklaşık olarak en iyi finansal performansı sağladığı söylenebilir.

\section{Giriș}

Her sektör gibi dokuma, giyim eşyası ve deri işletmeleri de rekabet etmek, süreklilik sağlamak ve yeni konseptlere yönelmek gibi stratejik hedeflerinin olması kaçınılmazdır. İşletmeler stratejik hedeflerine yönelik kararlar alabilmeleri için, geçmiş ve mevcut performanslarını görmek durumundadırlar. Bu nedenle, karar almayı kolaylaştıracak ve riskleri azaltacak performans bilgilerine ihtiyaç duyarlar. Performans ölçütlerinden birisi de finansal performanstır. Finansal performans bilgilerine ulaşmanın bir yolu da finansal analizlerdir. Finansal analiz için gerekli bilgiler de

\footnotetext{
* Sorumlu yazar/Corresponding author.

e-posta: muhammetsait.isildak@gop.edu.tr
} 
mali tablolardan sağlanır. Mali tablolar içerisinde yer alan en temel tablolar da bilanço ve gelir tablolarıdır. Performans ölçümünde, oran analizi yöntemi ve karşılaştırmalı mali analiz yöntemleri kullanılmaktadır (Gönenli, 1979:67). Karşılaştırmalı mali analiz, iki veya daha fazla döneme ait mali tablolar rakamsal ve yüzde olarak karşılaştırılabileceği gibi, dönemsel karşılaştırma veya gelişmelerinin incelenmesi şekliyle de yapılabilmektedir. Oran analizi ise, bilanço ve gelir tablosu kalemlerinin birbirleriyle oranlanması yoluyla hesaplanır. Oran analizi mali tablo kalemlerinin aralarındaki ilişkileri göstermektedir (Çetiner, 1996: 14).

İşletme performanslarının bilinmesinde klasik analiz yöntemleri bazen yeterli olamamaktadır. Bu durumda çok amaçlı karar verme (ÇAKV) analizlerine gerek duyulmaktadır. ÇAKV yöntemleri, birden fazla kriterin optimize edildiği, mümkün çözüm setlerinden en iyi sonucun seçildiği yöntemlerdir. Çok sayıda çok amaçlı karar verme analizi bulunmaktadır.

ÇAKV yöntemi olan VİKOR yöntemi, sınırlamalar doğrultusunda alternatifler arasından siralamalar yapılmasına olanak sağlamaktadır (Kuzu, 2015:117). VİKOR yönteminin amacı, maksimum grup faydası ve minimum bireysel pişmanlığı sağlayacak uzlaştırıcı çözüme ulaşmaktır (Karaoğlan vd. 2018:67). ÇAKV yöntemlerinde kriter ağırlıklarının kesin olduğu varsayılmaktadır. Kri $\neg$ ter ağırlıklarının belirlenmesinde sübjektif ölçütler kullanılabileceği gibi, analize bağlı yöntemler de kullanılabilir. Kriter ağırlıklarının belirlenmesinde Analitik Hiyerarşi Prosesi (AHP) kullanılabilmektedir.

$\mathrm{Bu}$ çalışmada, 5 ana grubu içeren toplam 18 alt oran kullanılmıştır. Kriter ağırlık ölçütleri AHP yöntemiyle belirlenmiştir. İşletmeleri finansal performansa göre sıralamada VİKOR yöntemi kullanılmıştır. BİST'te kayıtlı 20 adet dokuma, giyim eşyası ve deri işletmesinin 2014-2017 yıllarına ait bilanço ve gelir tablosu bilgileri kullanılmıştır. Kullanılan bilanço ve gelir tablosu bilgileri Kamuyu Aydınlatma Platformundan (KAP) sağlanmıştır.

\section{Literatür Taraması}

Literatürde AHP veya VİKOR yöntemini kullanarak finansal performans analizi yapan çalışmalardan bazıları aşağıda özetlenmiştir.

Akkaya ve Demireli (2010) çalışmalarında, kredi kuruluşlarının kredi verme sürecinde firmaların temel performans göstergesi olan finansal oranların ağırlık değerlendirmesini AHP yöntemini kullanarak bir model geliştirmişlerdir. 5 kategori altında 24 finansal oranın kredibilite üzerinde ne derece etkili olduğunu sıralayarak belirlemeye çalışmışlardır. Geliştirdikleri model sonucunda kredi kuruluşlarının en fazla faaliyet devir hızlarını göz önünde bulundurduklarını gözlemlemişlerdir.

Akyüz (2012) çalışmasında, mobilya parçaları üreten bir firmanın ambalaj tedarikçisi seçimini Bulanık VİKOR yöntemiyle incelemiştir. Yedi alternatiften iki alternatifin uzlaştırıcı çözüm olduğu sonucuna ulaşmıştır.

Apan vd. (2018) çalışmalarında, işletmelerin finansal başarısızlığını incelemişlerdir. BIST'te işlem gören Gıda ve İçecek Sektöründe faaliyet gösteren işletmelere ait 20082014 dönemi ait verilerini kullanarak ilk önce Altman'a göre
Z-Score yöntemini ve daha sonra VİKOR yöntemi sonuçlarını sıralamışlardır. $\mathrm{Bu}$ ampirik analiz sonuçlarını karşılaştırmışlar ve benzer sonuçlar verdiğini görmüşlerdir. İflas analizi için alternatif ve tamamlayıcı yöntem olduğunu belirtmişlerdir.

Ar vd. (2014) çalışmalarında, Rize'de kurulması planlanan eko turizm merkezinin yer seçimi analizinde bulanık AHS ve bulanık VİKOR yöntemlerini kullanmışlardır. Ağırlıklarının belirlenmesinde bulanık AHS, uzlaşık çözüm için bulanık VİKOR yaklaşımı kullanmışlardır. Yer seçim kararında en önemli kriter "yakın çevre" kriterinin ve otel yeri olarak da üç alternatiften "Kuspa" mevkiinin ön plana çıktığını belirtmişlerdir.

Bayrakdaroğlu ve Yalçın (2012) çalışmalarında, yedi stratejik finansal performans ölçütünü Bulanık AHP ve VİKOR yöntemi kullanarak İMKB-30 endeksinde işlem gören imalat sanayi işletmelerini 1998-2011 dönemlerini değerlendirmişlerdir. Performans ölçüt ağırlıklarını BAHP ile belirlemiş ve VİKOR yöntemi ile sıralamışlardır. En iyi uzlaşma çözümünün $\% 50$ seviyesinde sağlandığını belirtmişlerdir.

Chang ve Tsai (2016) çalışmalarında, 2007 yılı ortasından 2008 yılına kadar küresel finansal krizden etkilenen Taiwan'daki yedi ana varlık yönetimi bankasının finansal performans değerlendirmesini AHP ve VIKOR kullanarak yapmışlardır. Hizmet, performans, profesyonellik, risk kontrolü ve tüketici güveni kriterlerinden; hizmet, risk kontrolü ve tüketici güveni kriterlerinin en önemli kriterler olduklarını belirtmişlerdir.

Dinçer ve Görener (2011a) çalışmalarında, Türkiye'deki kamu, özel ve yabancı sermayeli bankaların 2002-2008 yıllarına ait finansal performanslarını AHP ve VİKOR yöntemleriyle analiz etmişlerdir. Kriter ağırlıklarını AHP yardımıyla performans ölçümünü de VİKOR yöntemi kullanılarak gerçekleştirilmiştir. 2002, 2003 ve 2008 yıllarında yabancı sermayeli bankaların, 2004-2007 yılları arasında ise kamu bankalarının en iyi performansı gösterdiği belirtmişlerdir.

Esbouei vd. (2014) çalışmalarında, Tahran Menkul Kiymetler Borsası'nda (TSE) işlem yapan 14 imalat endüstrisindeki 143 İran imalat işletmesi için bulanık AHP ve bulanık VİKOR yöntemleri birlikte kullanarak finansal performans değerlendirmesine hibrit yaklaşımda bulunmuşlardır. Sıralama sonucunda hibrit yaklaşımın önemli olduğunu söylemişlerdir.

Gök-Kısa ve Perçin (2018) çalışmalarında, VİKOR yöntemini kullanarak Global 2000 listesinde yer alan bilişim teknolojisi sektöründeki bilgisayar donanım firmalarının performans ölçümünü yapmışlardır. Kriter ağırlıklarının belirlenmesinde Entropi tekniği kullanılmışlar ve VİKOR yöntemiyle performans sıralaması yapmışlardır.

Göktolga ve Karakış (2018) çalışmalarında, bireysel emeklilik şirketlerinin 2014-2016 y1lları arası finansal performanslarını Bulanık AHP ve VİKOR yöntemleri ile değerlendirmişlerdir. Bulanık AHP ile kriterlerin önem dereceleri belirlemiş ve VİKOR yöntemi ile firmaların performans sıralama ve değerlendirme yapmışlardır. Yöntemlerin bütünleşik olarak kullanılabileceğini belirmişlerdir. 
İç vd. (2015) çalışmalarında, Türkiye ekonomisindeki 24 adet farklı sektör ve toplamda 198 adet kurumsal firmanın finansal performans değerlendirmesini TOPSİS, VİKOR, GRA ve MOORA yöntemlerini kullanarak karşılaştırmışlardır. Finansal performans değerlendirme modeli için en uygun sıralama yönteminin TOPSİS yöntemi olduğunu belirtmişlerdir.

Rezaie vd. (2014) çalışmalarında, Tahran Borsası'nda 27 İranlı çimento firmasının 2008 ve 2009 yıllarına ait finansal oranlar kullanarak performanslarını bulanık AHP ve VİKOR yöntemleriyle değerlendirmişlerdir. Performans ölçüt ağırlıklarını BAHP yöntemi ile belirlemiş ve performans sıralamışını da VİKOR yöntemi ile yapmışlardır.

Karaoğlan ve Şahin (2018) çalışmalarında, AHP, VİKOR, TOPSİS, GRA ve MOORA yöntemlerini kullanarak BİST Kimya, Petrol, Plastik Endeksi'nde (XKMYA) yer alan 24 işletmenin 2015 yılı finansal performanslarını incelemişlerdir. Kriter ağırlıkları AHP ile bulmuşlar ve VIKKOR, TOPSIS, GRA ve MOORA yöntemlerini karşılaştırarak finansal performansları sıralamışlardır.

Maya ve Eren (2017) çalışmalarında, İstanbul Menkul Kıymetler Borsası'nda kayıtlı gıda sektöründe bulunan ve 2014 yılında en büyük 1000 sanayi kuruluşu içine giren 12 işletmenin 2011-2015 yılları finansal performansları karşılaştırmışlardır. Kriter ağırlıklarını AHP ile bulmuşlar ve finansal performans karşılaştırmasında TOPSİS ve VİKOR yöntemlerini kullanmışlardır. Her iki yöntemin de birbirine yakın sonuçlar verdiğini bulmuşlardır.

Tezergil (2016) çalışmasında, Türk bankacılık sektöründe faaliyet gösteren 28 mevduat bankasının 2009-2013 yıllarına 9 finansal oran kullanarak VİKOR yöntemiyle finansal değerlendirme ve performans sıralaması yapmıştır.

Yalçın vd. (2012) çalışmalarında, geleneksel muhasebe temelli finansal performans ile değere dayalı finansal performans ölçütlerini karıştırarak yeni bir finansal performans değerlendirme yaklaşımı önermişlerdir. Kriter ağırlığını belirlemek için bulanık AHP yöntemi kullanmışlardır. Performans değerlemesinde VİKOR ve TOPSİS yöntemi kullanarak sıralama yapmışlardır. Sonuç olarak sıralamanın kendi sektörleriyle hemen hemen aynı olduğunu belirtmişlerdir.

Yanık ve Eren (2017) çalışmalarında, BIST-100 de işlem gören otomotiv imalat sektöründeki 11 işletme üzerinde 2011-2015 y1llarına ait finansal oranları kullanarak TOPSIS, VİKOR, ELECTRE yöntemlerinde finansal performans sıralaması yapmışlardır. Kriterlerin belirlenmesinde AHP yöntemi kullanmışlardır. Bütün yöntemlerde sonuçların hemen hemen benzer çıktığını belirtmişlerdir.

Yücenur (2018) çalışmasında, 5 farklı kasko poliçesi üreten sigorta şirketi için 5 kriter ve 22 alt kriterden oluşan hiyerarşik bir model kurup karşılaştırmıştır. Modelde bulanık AHP, bulanık ANP ve bulanık VIKKOR yöntemlerini kullanmıştır. Modelde 3 farklı yöntemle bulunan sonuçların birbirlerini destekler nitelikte olduğunu belirtmiştir.

\section{Araştırmada Kullanılan Yöntemler}

\subsection{AHP Yöntemi}

AHP, çok kriterli karar verme yöntemidir (Çakır, 2016:171). Çok kriterli karar verme, alternatif çözüm setlerinden en iyi olanı seçme, sınıflama ve sıralama yaparak karar almaya yardımcı olmaktır (Göksu, 2008:5). Çok sayıdaki kriterin önem derecesinin belirlemek ve tek boyuta indirgemektir (Turan, 2015:18). AHP, çok sayıda uzman karar vericilerin görüşlerini tek görüşe indirgeyerek ortak bir sonuca bağlar. (Önder, 2015:21). AHP, kriterlerin önem derecelerini belirlemenin yanında, kriterleri değerlendirme aracı olarak da kullanılmaktadır. AHP yöntemini ilk olarak kullanan Wind ve Saaty, kriterleri karşılaştırmada önem derecelerini gösteren ikili ölçek geliştirmiştir (Wind vd. 1980:644). Wind ve Saaty'nin ikili karşılaştırmalar için sunduğu önem dereceleri ve karşılıkları tablo 1 'de gösterilmiştir.

Tablo 1. İkili Karşılaştırmalar İçin Önem Dereceleri.

\begin{tabular}{|c|c|c|}
\hline Önem & Tanım & Açıklama \\
\hline 1 & $\begin{array}{l}\text { Eşit } \\
\text { derecede } \\
\text { önemli }\end{array}$ & İki faktör önemi eşittir. \\
\hline 3 & $\begin{array}{l}\text { Orta } \\
\text { derece } \\
\text { önemli }\end{array}$ & $\begin{array}{l}\text { Bir faktör diğerinden biraz daha } \\
\text { önemlidir. }\end{array}$ \\
\hline 5 & $\begin{array}{l}\text { Oldukça } \\
\text { önemli }\end{array}$ & $\begin{array}{l}\text { Bir faktör diğerinden kuvvetle } \\
\text { daha önemlidir. }\end{array}$ \\
\hline 7 & $\begin{array}{l}\text { Çok } \\
\text { önemli }\end{array}$ & $\begin{array}{l}\text { Bir faktör diğerinden yüksek } \\
\text { derecede kuvvetle önemlidir. }\end{array}$ \\
\hline 9 & $\begin{array}{l}\text { Son } \\
\text { derece } \\
\text { önemli }\end{array}$ & $\begin{array}{l}\text { Bir faktör diğerinden çok yüksek } \\
\text { derecede kuvvetle önemlidir. }\end{array}$ \\
\hline $2,4,6,8$ & $\begin{array}{l}\text { Ara } \\
\text { değerler }\end{array}$ & $\begin{array}{l}\text { Yukarıdaki tercihlerin } \\
\text { değerleridir. }\end{array}$ \\
\hline $\begin{array}{l}\text { Karşılık } \\
\text { değerleri } \\
\text { 1/önem } \\
\text { derecesi }\end{array}$ & \multicolumn{2}{|c|}{$\begin{array}{l}\mathrm{i}, \mathrm{j} \text { ile karşılaştırılırken atanan değer } \mathrm{x} \text { ise, } \\
\mathrm{j} \text { ile i karşılaştırılırken atanacak değer } 1 / \mathrm{x} \\
\text { olur. }\end{array}$} \\
\hline
\end{tabular}

Önem dereceleri uzmanlar kişilerce ikili karşılaştırma yapılarak karar matrisi oluşturulmuştur. Uzman kişilerin sayısına ve karar farklılıklarına göre kararları tek matrise dönüştürmek gerekecektir. Kararları tek matrise dönüştürmek, geometrik ortalama alınarak yapılabileceği gibi uzman kişilerin uzlaşısı veya başka bir uzman kişinin görüşü ile de yapılabilir. Yoğun kullanım geometrik ortalama yönündedir (Kuruüzüm, 2001:92). AHP yönteminin aşamaları aşağıdaki gibidir (Dinçer, 2011b:246).

1.Aşama: Analiz edilecek amaç, kriterler ve alternatifler belirlenir.

2.Aşama: Kriterler ve alternatifler için tablo 1'deki ölçek kullanılarak karar verici uzman kişiler tarafından ikili karşılaştırmalar yapılır. İkili karar matris (1) nolu eşitlikteki gibi oluşturulabilir. Matristeki üçgenin bir tarafı uzmanlar kişilerin ikili karşılaştırmalardan oluşurken diğer taraftaki 
üçgenin değerleri bu değerlerin tersinden oluşur. Ortadaki değerler $\left(a_{11}, a_{22}, . ., a_{n n}\right)$ ise, kendisiyle karşılaştırıldığ 1 için 1 'e eşittir (Abastante, 2019:112; Franek, 2014:165; Bana e Costa, 2008:1424).

$A_{i j}=\left[\begin{array}{cccc}a_{11} & a_{12} & \cdots & a_{1 n} \\ 1 / a_{12} & a_{22} & \cdots & a_{2 n} \\ \vdots & \vdots & \ddots & \vdots \\ 1 / a_{1 n} & 1 / a_{2 n} & \ldots & a_{n n}\end{array}\right]\left\{\mathrm{a}_{11}, \mathrm{a}_{22}, . ., \mathrm{a}_{\mathrm{nn}}\right\}=1$

2.Aşama: Çok sayıdaki uzman görüşten oluşan karar matrislerin geometrik ortalaması alınarak tek karar matrisine dönüştürülür. Geometrik ortalama çok sayıdaki uzman görüş kararlarının hatalarını en aza indirir (Ishizaka, 2011:14338). Krej`cía çalışmasında, AHP'de ağırlıklı geometrik ortalamanın kullanılmasını tavsiye etmiştir (Krejcía 2018:106). Geometrik ortalama (2) nolu formül kullanılarak hesaplanabilir.

$P=\sqrt[n]{\prod_{j=1}^{n} a_{i j}}$

3.Aşama: Karar matrisindeki her bir değer, (3) nolu formül kullanılarak kendi sütun toplamına bölünerek normalleştirilmiş matris $\left(\bar{a}_{i j}\right)$ elde edilir (Yang, 2009:278).

$\bar{a}_{i j}=\frac{a_{i j}}{\sum_{i=1}^{n} a_{i j}} \quad(\mathrm{i}, \mathrm{j}=1,2, \ldots, \mathrm{n})$
4.Aşama: Karar matrisindeki kriterlerin önem ağırlıklarını bulmak için, (4) nolu formül kullanılarak her bir satır toplamının ortalaması alınır (Yang, 2009:278).

$w_{i}=\frac{\sum_{i=1}^{n} \bar{a}_{i j}}{n} \quad(\mathrm{i}=1,2, \ldots, \mathrm{n})$

5.Aşama: Önem ağırlıklarının tutarlı olup olmadığı test edilir. Tutarlılık oranı (CR), (5) nolu formül kullanılarak hesaplanır (Ömürbek, 2014:195). Tutarlılık oranının $\% 10$ 'dan daha düşük olması gerekir. Tutarlılık oranının \%10'dan daha büyük olması, uzman görüşlerinin gözden geçirilmesini gerektirir.

$C R=\frac{C I}{R I}$

Tutarlılık indeksi (CI), (6) nolu formül kullanılarak hesaplanır.

$C I=\frac{(\lambda \max -n)}{(n-1)}$

Formüldeki $\lambda \max$, matristeki en büyük öz değeri; $n$ ise, kriter sayısını göstermektedir. Kriter sayısı 15 'ten büyük boyutlar için rassal indeks (RI) tablo 2'de verilmiştir (Alonso, 2018:452).

Tablo 2: Kriter Sayıs1 15 'ten Büyük Boyutlar için Rasgele İndeks Tablosu.

\begin{tabular}{llllllllllll}
\hline $\mathbf{n}$ & 1 & 2 & 3 & 4 & 5 & 6 & 7 & 8 & 9 & 10 \\
RI & 0 & 0 & 0,58 & 0,9 & 1,12 & 1,24 & 1,32 & 1,41 & 1,45 & 1,49 \\
$\mathbf{n}$ & 11 & 12 & 13 & 14 & 15 & 16 & 17 & 18 & 19 & 20 \\
$\mathbf{R I}$ & 1,49 & 1,52 & 1,54 & 1,56 & 1,58 & 1,5978 & 1,6086 & 1,6181 & 1,6265 & 1,6341 \\
$\mathbf{n}$ & 21 & 22 & 23 & 24 & 25 & 26 & 27 & 28 & 29 & 30 \\
RI & 1,6409 & 1,647 & 1,6526 & 1,6577 & 1,6624 & 1,6667 & 1,6706 & 1,6743 & 1,6777 & 6809 \\
n & 31 & 32 & 33 & 34 & 35 & 36 & 37 & 38 & 39 & 40 \\
RI & 1,6839 & 1,6867 & 1,6893 & 1,6917 & 1,694 & 1,6962 & 1,6982 & 1,7002 & 1,702 & 1,70485 \\
\hline
\end{tabular}

\subsection{VİKOR Yöntemi}

Çok kriterli karar verme yöntemi olan VİKOR, alternatifler arasında ideale en yakın alternatifi belirlemek olarak bilinmektedir. Bütün çok kriterli karar verme yöntemlerinde olduğu gibi VİKOR yönteminde de kriter ağırlıklarının bilindiği kabul edilmektedir. VİKOR yöntemi, ideale en yakın alternatifi belirlemek için sıralanmış uzlaşık çözüm sunar (Opricovic, 2004:447). Opricovic ve Tzeng tarafindan geliştirilen VİKOR yöntemi beş aşamada çözülmekte olup sürecin adımları şöyledir.

1. Adım: İlk önce her bir kriter için alternatiflerin aldığı en iyi ve en kötü değerler belirlenir. Eğer j kriteri fayda özellikli ise;

$f_{i}^{*}=\max _{j} f_{i j}, \quad f_{i}^{-}=\min _{j} f_{i j} \quad(\mathrm{i}=1,2, \ldots . \mathrm{n})$

j kriteri maliyet özellikli ise;

$f_{i}^{*}=\min _{j} f_{i j}, \quad f_{i}^{-}=\max _{j} f_{i j} \quad(\mathrm{i}=1,2, \ldots . \mathrm{n})$ olarak ifade edilir.
2. Adım: Ortalama skor $\left(S_{j}\right)$ ve en kötü skor $\left(R_{j}\right)$ değerleri (7 ve 8) nolu formüller kullanılarak hesaplanır. Burada $w_{i}$, kriter ağırlığını ifade eder.

$S_{j=} \sum_{i=1}^{n} w_{i}\left(f_{i}^{*}-f_{i j}\right) /\left(f_{i}^{*}-f_{i}^{-}\right) \quad(\mathrm{j}=1,2, \ldots \mathrm{J})$

$R_{j}=\max _{i}\left[w_{i}\left(f_{i}^{*}-f_{i j}\right) /\left(f_{i}^{*}-f_{i}^{-}\right)\right] \quad(\mathrm{j}=1,2, \ldots \mathrm{J})$

3. Adım: Kriterlerin maksimum grup (Q) faydası değerleri (9) nolu formül yardımıyla bulunabilir. Burada, v, maksimum grup faydasının stratejik ağırlığını gösterirken $1 / v$, karşıt grupların minimum pişmanlığını gösterir.

$Q=\left[\frac{v\left(S_{j}-S^{*}\right)}{S^{-}-S^{*}}\right]+\left[\frac{1-v\left(R_{j}-R^{*}\right)}{R^{-}-R^{*}}\right]$

4. Adım: Alternatiflerin S, R ve Q değerleri küçükten büyüğe doğru siralanır.

5. Adım: Sıralanan alternatiflerin doğruluğu iki koşul ile test edilir. 
1. Koşul: Kabul edilebilir avantaj koşuludur. İlk sıradaki alternatif $a^{\prime}$ ve ikinci sıradaki alternatif $a^{\prime \prime}$ göstermek üzere kabul edilebilir avantaj (10) nolu formül ile bulunabilir.

$$
Q\left(a^{\prime \prime}\right)-Q\left(a^{\prime}\right) \geq D Q
$$

Alternatif sayısına göre DQ değeri de değişecektir. DQ parametresi (11) nolu eşitlikle bulunur. Burada J, alternatif sayısını ifade etmektedir.

$$
D Q=\frac{1}{J-1}
$$

2. Koşul: Kabul edilebilir istikrar koşuludur. $a^{\prime}, \mathrm{S}$ ve/veya $\mathrm{R}$ değerlerine göre minimum değerli en iyi alternatif olmalıdır.

Alternatiflerin her ikisi de sağlanıyorsa uzlaşık çözüm vardır. Eğer koşul 2 sağlanmıyorsa $a^{\prime}$ ve $a^{\prime \prime}$ alternatiflerinin ikisi de uzlaşık çözümdür. Eğer Koşul 1 sağlanmıyorsa, üst sınır değeri "M" maksimumu göstermek üzere uzlaşık çözüm (12) nolu eşitliğe göre belirlenir.
$Q\left(a^{M}\right)-Q\left(a^{\prime}\right)<D Q$

Q değerlerine göre sıralandığında minimum $\mathrm{Q}$ değerine sahip alternatif en iyi uzlaşık çözümü sağlayan alternatiftir.

\section{Araștırmada Kullanılan Veriler ve Metodoloji}

Çalışmada, BİST'te işlem gören mali tablo bilgilerine ulaşılabilen ve daha önce üzerinde çalışılmamış alan olan 20 adet dokuma, giyim eşyası ve deri işletmesinin finansal oranları kullanılarak AHP ve VİKOR yöntemi aracılığıyla performans ölçümlemesi yapılmıştır. Kriter ağırlıkları AHP yöntemi kullanılarak sağlanmış ve daha sonra VİKOR yönteminde uygulanarak performans sıralaması yapılmıştır. Mali tablo bilgileri Kamuyu Aydınlatma Platformu (KAP) internet adresinden sağlanmıştır. AHP ve VİKOR yönteminde kullanılan oranlar tablo 3 'de verilmiştir.

\begin{tabular}{|c|c|c|}
\hline & Likidite Oranları & \\
\hline CO & Cari Oran & Dönen Varlıklar /Kısa Vadeli Borç \\
\hline LO & Likidite oranı & (Dönen Varlıklar-Stoklar) /Kısa Vadeli Borç \\
\hline NO & Nakit Oranı & Hazır değerler /Kısa Vadeli Borç \\
\hline \multirow[t]{2}{*}{ SBO } & Stok Bağımlılık Oranı & Kısa Vadeli Yabancı Kaynaklar- (Hazır Değerler+ Menkul Kıymetler) / Stoklar \\
\hline & Faaliyet Oranları & \\
\hline ALD & Alacak Devir Hızı Oranı & Net Satışlar / Ortalama Ticari Alacaklar \\
\hline SDH & Stok Devir Hızı Oranı & Satışların Maliyeti / Ortalama Stok \\
\hline AKD & Aktif Devir Hızı Oranı & Net Satışlar / Ortalama Aktifler \\
\hline \multirow[t]{2}{*}{ OZD } & Öz Kaynak Devir Hızı Oranı & Net Satı̧lar / Ortalama Öz Sermaye \\
\hline & Mali Durum Oranları & \\
\hline KO & Kaldıraç Oranı & Yabancı Kaynaklar/ Toplam Aktif \\
\hline FO & Finansman Oranı & Öz Kaynaklar/Yabancı Kaynaklar \\
\hline YO & Yatırım Oranı & Duran Varlık /Öz Kaynak \\
\hline \multirow[t]{2}{*}{ KVK } & KVYK/Toplam Kaynak Oranı & Kısa Vadeli Yabancı Kaynak/Toplam Kaynak \\
\hline & Kârlılık Oranları & \\
\hline SK & Satışların Kârlılığı Oranı & Net Kâr / Net Satışlar \\
\hline OK & Öz sermaye Kârlılığı Oranı & Net Kâr / Öz Sermaye \\
\hline AK & Aktiflerin Karlılığ 1 Oranı & Net Kâr / Aktif Toplamı \\
\hline \multirow[t]{2}{*}{ FKO } & Faiz Karşılama Oranı & (Dönem Karı + Faiz Giderleri) /Faiz Giderleri \\
\hline & Piyasa Değeri Oranları & \\
\hline HBK & Hisse Başına Kâr Oranı & Net Kâr / Hisse Senedi Sayısı \\
\hline PDD & $\begin{array}{l}\text { Piyasa Değeri / } \\
\text { Defter Değeri Oranı }\end{array}$ & (Hisse Senedi Sayıs1 * Hisse Senedi Fiyatı) / (Toplam Pasif -Toplam Borçlar) \\
\hline
\end{tabular}

Tablo 3. Hesaplamalarda Kullanılacak Oranlar.

Makale yazım k1sıtlarından dolayı 2014-2017 y1larına ait hesaplamalar yapılmış olup burada gösterilememiştir. Örnek olması için sadece 2017 yılına ait AHP ve VİKOR çözümü gösterilmiştir. Sonuçlar karşılaştırılırken 2014-2017 yıllarına ait hesaplamalar da kullanılacaktır. AHP ve VİKOR yöntemi çözümleri, Microsoft Excel programı kullanılarak gerçekleştirilmiştir. Çalışmada BIST'te işlem gören dokuma, giyim eşyası ve deri işletmesinin listesi aşağıda Tablo 4'de verilmiştir. 


\begin{tabular}{|c|c|c|c|}
\hline Kod & Şirket Adı & Kod & Şirket Adı \\
\hline DESA & Desa Deri Sanayi ve Ticaret A.Ş. & ARSAN & Arsan Tekstil Ticaret ve Sanayi A.Ş. \\
\hline DIRIT & Diriteks Diriliş Tekstil Sanayi ve Ticaret A.Ş. & YUNSA & Yünsa Yünlü Sanayi ve Ticaret A.Ş. \\
\hline SKTAS & Söktaş Tekstil Sanayi ve Ticaret A.Ş. & SNPAM & Sönmez Pamuklu Sanayii A.Ş. \\
\hline MNDRS & Menderes Tekstil Sanayi ve Ticaret A.Ş. & BOSSA & Bossa Ticaret ve Sanayi İşletmeleri T.A.Ş. \\
\hline RODRG & Rodrigo Tekstil Sanayi ve Ticaret A.Ş. & KORDS & Kordsa Teknik Tekstil A.Ş. \\
\hline BRKO & $\begin{array}{l}\text { Birko Birleşik Koyunlular Mensucat Ticaret ve } \\
\text { Sanayi A.Ş. }\end{array}$ & KRTEK & ekstil Sanayii ve Ticaret A.Ş. \\
\hline DAGI & Dagi Giyim Sanayi ve Ticaret A.Ş. & HATEK & Hateks Hatay Tekstil İşletmeleri A.Ş. \\
\hline LUKSK & Lüks Kadife Ticaret ve Sanayii A.Ş. & BLCYT & Bilici Yatırım Sanayi ve Ticaret A.Ş. \\
\hline ATEKS & Akın Tekstil A.Ş. & DERIM & $\begin{array}{l}\text { Derimod Konfeksiyon Ayakkabı Deri Sanayi ve } \\
\text { Ticaret A.Ş. }\end{array}$ \\
\hline YATAS & Yataş Yatak ve Yorgan Sanayi ve Ticaret A.Ş. & BRMEN & Birlik Mensucat Ticaret ve Sanayi İşletmesi A.Ş. \\
\hline
\end{tabular}

\subsection{AHP Yöntemi ile Ağırlıkların Bulunması:}

AHP Yönteminde kullanılacak kriterler, BİST’te işlem gören dokuma, giyim eşyası ve deri işletmelerinin bilanço ve gelir tablolarından sağlanmış 18 adet finansal orandan oluşmaktadır. Kriterlerin önem derecelendirilmesi için, karar verici üç uzman öğretim elemanı tarafindan tablo 1'deki Wind ve Saaty'nin ikili karşılaştırma ölçeğine göre karşılaştırma yapmaları istenmiş ve karar matrisine dönüştürülmüştür. Karar matrisine dönüştürülen matrisler (2) nolu formül kullanılarak geometrik ortalama yoluyla tek karar matrisine dönüştürülmüş ve tablo 5'de verilmiştir.

Tablo 5. Kriterlerin İkili Karşılaş̧ırmalarının Geometrik Ortalaması Alındıktan Sonraki Durumu.

\begin{tabular}{|c|c|c|c|c|c|c|c|c|c|c|c|c|c|c|c|c|c|c|}
\hline & $\mathrm{CO}$ & LO & NO & SBO & ALD & SDH & AKD & OZD & KO & FO & YO & KVK & SK & OK & AK & FKO & HBK & PDD \\
\hline $\mathrm{CO}$ & 1,00 & 1,91 & 1,71 & 6,26 & 0,58 & 1,53 & 2,03 & 0,52 & 1,29 & 5,28 & 0,69 & 1,19 & 0,13 & 0,19 & 0,21 & 1,29 & 0,44 & 0,15 \\
\hline LO & 0,52 & 1,00 & 0,48 & 2,08 & 0,36 & 0,39 & 4,22 & 2,14 & 0,82 & 6,26 & 0,65 & 0,84 & 0,14 & 0,15 & 0,17 & 1,00 & 0,19 & 0,13 \\
\hline NO & 0,58 & 2,08 & 1,00 & 6,26 & 0,54 & 0,48 & 1,86 & 1,53 & 1,44 & 1,44 & 3,56 & 2,27 & 0,25 & 0,25 & 0,52 & 1,53 & 0,36 & 0,52 \\
\hline SBO & 0,16 & 0,48 & 0,16 & 1,00 & 0,52 & 0,41 & 0,47 & 0,39 & 0,69 & 0,44 & 0,52 & 0,44 & 0,13 & 0,15 & 0,17 & 0,19 & 0,16 & 0,15 \\
\hline ALD & 1,71 & 2,76 & 1,86 & 1,91 & 1,00 & 6,26 & 2,27 & 1,71 & 1,61 & 1,71 & 1,57 & 1,53 & 0,48 & 0,57 & 0,48 & 1,29 & 0,49 & 0,39 \\
\hline SDH & 0,65 & 2,54 & 2,08 & 2,47 & 0,16 & 1,00 & 5,00 & 3,98 & 1,91 & 0,69 & 0,69 & 1,91 & 0,17 & 0,19 & 0,19 & 0,58 & 0,39 & 0,36 \\
\hline AKD & 0,49 & 0,24 & 0,54 & 2,14 & 0,44 & 0,20 & 1,00 & 0,58 & 1,44 & 1,61 & 0,58 & 1,19 & 0,13 & 0,14 & 0,16 & 0,92 & 0,13 & 0,15 \\
\hline OZD & 1,91 & 0,47 & 0,65 & 2,54 & 0,58 & 0,25 & 1,71 & 1,00 & 2,27 & 1,91 & 1,41 & 1,44 & 0,15 & 0,15 & 0,48 & 2,27 & 0,39 & 0,49 \\
\hline KO & 0,78 & 1,22 & 0,69 & 1,44 & 0,62 & 0,18 & 0,69 & 0,44 & 1,00 & 0,21 & 0,52 & 0,54 & 0,20 & 0,18 & 0,17 & 0,44 & 0,39 & 0,36 \\
\hline FO & 0,19 & 0,16 & 0,69 & 2,27 & 0,58 & 0,49 & 0,62 & 0,52 & 4,72 & 1,00 & 2,27 & 0,57 & 0,18 & 0,18 & 0,21 & 0,52 & 0,47 & 0,43 \\
\hline YO & 1,44 & 1,53 & 0,28 & 1,91 & 0,64 & 1,44 & 1,71 & 0,71 & 1,91 & 0,44 & 1,00 & 0,69 & 0,16 & 0,44 & 0,19 & 1,44 & 0,16 & 0,16 \\
\hline KVK & 0,84 & 1,19 & 0,44 & 2,27 & 0,65 & 0,52 & 0,84 & 0,69 & 1,86 & 1,75 & 1,44 & 1,00 & 0,15 & 0,15 & 0,16 & 0,58 & 0,19 & 0,17 \\
\hline SK & 7,61 & 7,00 & 3,98 & 7,61 & 2,08 & 5,74 & 7,00 & 6,80 & 5,00 & 5,59 & 6,26 & 6,80 & 1,00 & 6,26 & 5,00 & 5,28 & 3,27 & 2,14 \\
\hline OK & 5,28 & 6,80 & 3,98 & 6,80 & 1,75 & 5,13 & 6,26 & 6,80 & 5,59 & 5,59 & 2,27 & 6,80 & 0,16 & 1,00 & 1,33 & 2,92 & 0,54 & 0,48 \\
\hline AK & 4,72 & 5,74 & 1,91 & 5,74 & 2,08 & 5,13 & 2,14 & 6,08 & 5,74 & 4,72 & 5,28 & 6,24 & 0,20 & 0,75 & 1,00 & 3,66 & 0,78 & 0,54 \\
\hline FKO & 0,78 & 1,00 & 0,65 & 5,28 & 0,78 & 1,71 & 1,09 & 0,44 & 2,27 & 1,91 & 0,69 & 1,71 & 0,19 & 0,34 & 0,27 & 1,00 & 0,16 & 0,15 \\
\hline HBK & 2,27 & 5,13 & 2,76 & 6,08 & 2,03 & 2,54 & 7,61 & 2,54 & 2,54 & 2,14 & 6,26 & 5,28 & 0,31 & 1,86 & 1,29 & 6,26 & 1,00 & 0,15 \\
\hline PDD & 6,80 & 7,61 & 1,91 & 6,80 & 2,54 & 2,76 & 6,80 & 2,03 & 2,76 & 2,33 & 6,26 & 5,74 & 0,47 & 2,08 & 1,86 & 6,80 & 6,80 & 1,00 \\
\hline Toplam & 37,7 & 48,8 & 25,8 & 70,9 & 18,4 & 36,2 & 53,3 & 38,9 & 44,9 & 45,0 & 41,9 & 46,2 & 4,6 & 15,0 & 13,9 & 38,0 & 16,3 & 7,9 \\
\hline
\end{tabular}

Karar matrisindeki her bir değer, (3) nolu formül kullanılarak kendi sütun toplamına bölünerek normalleştirilmiştir. Daha sonra, karar matrisindeki kriterlerin önem ağırlıklarını bulmak için, (4) nolu formül kullanılarak her bir satır toplamının ortalaması alınarak önem ağırlığ 1 (w) hesaplanarak tablo 6'da verilmiştir. 
Tablo 6. Kriterler Normalleştirilmesi ve Öncelikler Vektörü (w) Bulunması.

\begin{tabular}{|c|c|c|c|c|c|c|c|c|c|c|c|c|c|c|c|c|c|c|c|}
\hline & 0 & LO & NO & $\overline{\mathrm{BO}}$ & D & $\mathrm{OH}$ & $\overline{\text { AKD }}$ & $\overline{\text { DZD }}$ & KO & FO & YO & VK & SK & K & AK & FKO & HBK & PDD & $W$ \\
\hline$\overline{\mathrm{CO}}$ & 0,03 & 0,04 & 0,07 & 0,09 & 0,03 & 0,04 & 0,04 & 0,01 & 0,03 & 0,12 & 0,02 & 0,03 & 0,03 & 0,01 & 0,02 & 0,03 & 0,03 & 0,02 & 0,04 \\
\hline LO & 1 & 0,02 & 0,02 & 0,03 & 0,02 & 0,01 & 0,08 & 0,05 & 0,02 & 0,14 & 0,02 & 0,02 & 0,03 & 0,01 & 0,01 & 0,03 & 0,01 & 22 & 0,03 \\
\hline NO & 2 & ,04 & 0,04 & 0,09 & 3 & 01 & 03 & 04 &, 03 & 0,03 & 0,08 & 0,05 & 0,05 & 0,02 & 0,04 & 0,04 & 0,02 & 0,07 & 0,04 \\
\hline SBO & 00 & 01 & 01 & 0,01 & 03 & 0,01 & 0,01 & 0,01 & 0,02 & 0,01 & 0,01 & 0,01 & 0,03 & 0,01 & 0,01 & 0,00 & 0,01 & 0,02 & 0,01 \\
\hline ALD & 05 & 0,06 & 0,07 & 0,03 & 0,05 & 0,17 & 0,04 & 0,04 & 0,04 & 0,04 & 0,04 & 0,03 & 0,10 & 0,04 & 0,03 & 0,03 & 0,03 & 0,05 & 0,05 \\
\hline OH & 02 & 05 & 08 & 03 & & 03 & 09 & 10 & 04 & 0,02 & 0,02 & 0,04 & 0,04 & 0,01 & 0,01 & 0,02 & 0,02 & 0,05 & 0,04 \\
\hline AKD & 01 & 00 & 02 & 0,03 & 0,02 & 0,01 & 0,02 & 0,02 & 0,03 & 0,04 & 0,01 & 0,03 & 0,03 & 0,01 & 0,01 & 0,02 & 0,01 & 0,02 & 0,02 \\
\hline OZD & 0,05 & 0,01 & 0,03 & 0,04 & 0,03 & 0,01 & 0,03 & 0,03 & 0,05 & 0,04 & 0,03 & 0,03 & 0,03 & 0,01 & 0,03 & 0,06 & 0,02 & 0,06 & 0,03 \\
\hline $\mathbf{O}$ & 0,02 & 0,02 & 0,03 & 02 & 0 & 0,00 & 0 & 01 & 0,02 & 0,00 & 0,01 & 0,01 & 0,04 & 0,01 & 0,01 & 0,01 & 0,02 & 0,05 & 0,02 \\
\hline FO & 0,01 & 0,00 & 0,03 & 0,03 & 0,03 & 0,01 & 0,01 & 0,01 & 0,11 & 0,02 & 0,05 & 0,01 & 0,04 & 0,01 & 0,02 & 0,01 & 0,03 & 0,05 & 0,03 \\
\hline YO & 0,04 & ,03 & 0,01 & 0,03 & 0,04 & 0,04 & 0,03 & 0,02 & 0,04 & 0,01 & 0,02 & 0,02 & 0,03 & 0,03 & 0,01 & 0,04 & 0,01 & 0,02 & 0,03 \\
\hline VK & 02 & 02 & 02 & 03 & T' & ,01 & 02 & 0,02 & 0,04 & 0,04 & 0,03 & 0,02 & 0,03 & 0,01 & 0,01 & 0,02 & 0,01 & 0,02 & 0,02 \\
\hline SK & 0,20 & 0,14 &, 15 & ,11 & 11 & 0,16 & 0,13 & 0,17 & 0,11 & 0,12 & 0,15 & 0,15 & 0,22 & 0,42 & 0,36 & 0,14 & 0,20 & 0,27 & 0,18 \\
\hline OK & 0,14 & 0,14 & 0,15 & 0,10 & 0,10 & 0,14 & 0,12 & 0,17 & 0,12 & 0,12 & 0,05 & 0,15 & 0,03 & 0,07 & 0,10 & 0,08 & 0,03 & 0,06 & 0,10 \\
\hline IK & 12 & 12 &, 07 & 0,08 & 0,11 & 0,14 & 0,04 & 0,16 & 0,13 & 0,10 & 0,13 & 0,14 & 0,04 & 0,05 & 0,07 & 0,10 & 0,05 & 0,07 & 0,10 \\
\hline FKO & 0,02 & 0,02 & 0,03 & 0,07 & 0,04 & 0,05 & 0,02 & 0,01 & 0,05 & 0,04 & 0,02 & 0,04 & 0,04 & 0,02 & 0,02 & 0,03 & 0,01 & 0,02 & 0,03 \\
\hline BK & 0,06 & 0,11 & 0,11 & 0,09 & & 0,07 & 0 , & 0,07 & 0,06 & 0,05 & 0,15 & 0,11 & 0,07 & 0,12 & 0,09 & 0,16 & 0,06 & 0,02 & 0,09 \\
\hline DD & 18 & 16 &, 07 & 10 & 0,14 & 0,08 & 0,13 & 0,05 & 0,06 & 0,05 & 0,15 & 0,12 & 0,10 & 0,14 & 0,13 & 0,18 & 0,42 & 0,13 & 0,13 \\
\hline
\end{tabular}

Bu aşamada önem ağırlıklarının tutarlı olup olmadığı test edilmesi gerekir. Kriterlerin ikili karşılaştırmalarının geometrik ortalaması alındıktan sonraki değerler üzerinden en büyük öz değer $(v)$ hesaplanıp tablo 7'de verilmiştir.

Tablo 7. En Büyük Öz Değerin (v) Bulunmas1.

\begin{tabular}{|c|c|c|c|c|c|c|c|c|c|c|c|c|c|c|c|c|c|c|c|c|}
\hline & $\mathrm{CO}$ & LO & NO & SBO & ALD & SDH & AKD & OZD & KO & FO & YO & KV & SK & OK & AK & FKO & HBK & PDD & $v$ & $v / w$ \\
\hline $\mathrm{CO}$ & 0,04 & 0,06 & 0,07 & 0,08 & 0,03 & 0,06 & 0,04 & 0,02 & 0,03 & 0,14 & 0,02 & 0,03 & 0,02 & 0,02 & 0,02 & 0,04 & 0,04 & 0,02 & 0,77 & 20,64 \\
\hline LO & 02 &, 03 & 02 & ,03 & 0,02 & 0,01 & 0,08 & 0,07 & 0,02 & 0,17 & 0,02 & 0,02 & 0,03 & 0,02 & 0,02 & 0,03 & 0,02 & 0,02 & 63 & 75 \\
\hline NO & 02 & 0,06 &, 04 & 08 & 0,03 & 02 & 0,04 & 0,05 & 0,03 & 0,04 & 10 & 0,05 &, 05 &, 03 & 0,05 & 05 & 03 & 0,07 &, 83 & ,18 \\
\hline SBO & 01 & 0,01 & 0,01 & 0,01 & 0,03 & 0,02 & 0,01 & 0,01 & 0,01 & 0,01 & 0,01 & 0,01 & 0,02 & 0,02 & 0,02 & 0,01 & 0,01 & 0,02 & 0,25 & 20,14 \\
\hline ALD & 0,06 & 0,08 & 0,08 & 0,02 & 0,05 & 0,24 & 0,04 & 0,06 & 0,03 & 0,05 & 0,04 & 0,04 & 0,09 & 0,06 & 0,05 & 0,04 & 0,04 & 0,05 & 1,13 & ,32 \\
\hline SDH & 02 & 0,08 & 0,09 & 03 & 0,01 & 0,04 & 0,09 & 0,13 & 0,04 & 0,02 & 0,02 & 0,04 & 03 & 02 & 0,02 & 0,02 & 0,04 & 0,05 & 78 & 64 \\
\hline AKD & 0,02 & 0,01 & 0,02 & 0,03 & 0,02 & 0,01 & 0,02 & 0,02 & 0,03 & 0,04 & 0,02 & 0,03 & 0,02 & 0,01 & 0,02 & 0,03 & 0,01 & 0,02 & 0,37 & 19,77 \\
\hline OZD & 0,07 & 0,01 & 0,03 & 0,03 & 0,03 & 0,01 & 0,03 & 0,03 & 0,04 & 0,05 & 0,04 & 0,03 & 0,03 & 0,02 & 0,05 & 0,07 & 0,04 & 0,07 & 0,68 & 10 \\
\hline KO & 0,03 & 0,04 & 0,03 & 02 & 0,03 & 0,01 & 0,01 & 0,01 & 0,02 & 0,01 & 0,01 & 0,01 & 0,04 & 0,02 & 0,02 & 0,01 & 0,04 & 0,05 & 0,40 &, 29 \\
\hline FO & 0,01 & 0,00 & 0,03 & 0,03 & 0,03 & 0,02 & 0,01 & 0,02 & 0,09 & 0,03 & 0,06 & 0,01 & 0,03 & 0,02 & 0,02 & 0,02 & 0,04 & 0,06 & 0,53 & 19,35 \\
\hline YO & 0,05 & 0,05 & 0,01 & 0,02 & 0,03 & 0,05 & 0,03 & 0,02 & 0,04 & 0,01 & 0,03 & 0,02 & 0,03 & 0,05 & 0,02 & 0,04 & 0,01 & 0,02 & 0,55 & 20 \\
\hline KVK & 0,03 & 0,04 & 0,02 & 0,03 & 0,03 & 0,02 & 0,02 & 0,02 & 0,04 & 0,05 & 0,04 & 0,02 & 0,03 & 0,02 & 0,02 & 0,02 & 0,02 & 0,02 & 0,47 & 0,27 \\
\hline SK & 0,28 & 0,21 & 0,16 & 0,09 & 0,11 & 0,22 & 0,13 & 0,23 & 0,10 & 0,15 & 0,17 & 0,16 & 0,18 & 0,65 & 0,48 & 0,16 & 0,30 & 0,28 & 4,08 & 22,12 \\
\hline OK & 0,20 & 0,21 & 0,16 & 0,08 & 0,09 & 0,19 & 0,12 & 0,23 & 0,11 & 0,15 & 0,06 & 0,16 & 0,03 & 0,10 & 0,13 & 0,09 & 0,05 & 0,06 & 2,23 & 1,38 \\
\hline AK & 0,18 & 0,17 & 0,08 & 0,07 & 0,11 & 0,19 & 0,04 & 0,20 & 0,11 & 0,13 & 0,15 & 0,14 & 0,04 & 0,08 & 0,10 & 0,11 & 0,07 & 0,07 & 2,04 & 21,40 \\
\hline FKO & 0,03 & 0,03 & 0,03 & 0,07 & 0,04 & 0,06 & 0,02 & 0,01 & 0,04 & 0,05 & 0,02 & 0,04 & 0,03 & 0,04 & 0,03 & 0,03 & 0,01 & 0,02 & 0,61 & 20,09 \\
\hline HBK & 0,08 & 0,16 & 0,11 & 0,08 & 0,11 & 0,10 & 0,14 & 0,08 & 0,05 & 0,06 & 0,17 & 0,12 & 0,06 & 0,19 & 0,12 & 0,19 & 0,09 & 0,02 & 1,94 & 21,26 \\
\hline PDD & 0,25 & 0,23 & 0,08 & 0,08 & 0,13 & 0,10 & 0,13 & 0,07 & 0,05 & 0,06 & 0,17 & 0,13 & 0,09 & 0,22 & 0,18 & 0,21 & 0,62 & 0,13 & 2,95 & 22,26 \\
\hline
\end{tabular}

Daha sonra elde edilen en büyük öz değer (v) matris elemanları öncelikler vektörü (w) elemanlarına (tablo 7'de verilmiştir.) bölünür. Daha sonra toplamların ortalaması alınarak (6) nolu formül yardımıyla tutarlılık endeksi bulunur. Tutarlılık endeksi, $(\mathrm{CI})=((20,70-18)) /((18-$ $1))=0,16$ bulunmuştur. Tablo 2 'deki rassallık endeksi ile tutarlılık endeksi 5 nolu formülde yerine konulduğunda tutarlılık oranı, $(\mathrm{CR})=0,16 / 1,6181=0,098$ bulunur. Bu oran, $0,098<0,01$ eşitliğini sağladığı için, önem ağırlıklarının uyum sınırları içinde olduğu kabul edilebilir. Sonuç olarak AHP yoluyla hesaplanan oran ağırlıkları (w) ve sıralaması tablo 8'de verilmiştir. Bu ağırlıklar, VİKOR yönteminde oran ağırlıkları olarak kullanılacaktır.

Tablo 8. Oran Ağırlıkları ve Sıralaması.

\begin{tabular}{|c|c|c|c|c|c|c|c|c|c|c|c|c|c|c|c|c|c|c|}
\hline & $\mathrm{CO}$ & LO & NO & SBO & ALD & SDH & AKD & OZD & KO & FO & YO & KVK & SK & OK & AK & FKO & HBK & PDD \\
\hline$w$ & 0,04 & 0,03 & 0,04 & 0,01 & 0,05 & 0,04 & 0,02 & 0,03 & 0,02 & 0,03 & 0,03 & 0,02 & 0,18 & 0,10 & 0,10 & 0,03 & 0,09 & 0,13 \\
\hline Sira & 10 & 5 & 11 & 1 & 13 & 12 & 2 & 6 & 3 & 7 & 8 & 4 & 18 & 15 & 16 & 9 & 14 & 17 \\
\hline
\end{tabular}


4.2. VIKOR Yöntemiyle Performans Siralaması

BİST'te işlem gören dokuma, giyim eşyası ve deri işletmelerinin finansal oranlarını ve kriter özelliklerini içeren matris oluşturularak tablo 9'da sunulmuştur.

Tablo 9. BİST’te İşlem Gören Dokuma, Giyim Eşyası ve Deri İşletmelerinin Finansal Oranları.

\begin{tabular}{|c|c|c|c|c|c|c|c|c|c|c|c|c|c|c|c|c|c|c|}
\hline 017 & $\mathbf{O}$ & $\mathbf{O}$ & $\mathbf{O}$ & & LD & & 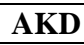 & $\mathbf{Z D}$ & & $\overline{\mathbf{O}}$ & $\overline{\mathbf{O}}$ & & $\mathbf{K}$ & $\bar{K}$ & AK & FКU & $18 \mathrm{~N}$ & - \\
\hline Kriter Öz. & Max & $\operatorname{Iax}$ & Iax & Iin & Max & Tax & Max & Max & Min & Max & ITy & Min & Max & Max & Max & Max & Max & Max \\
\hline TEKS & 1,33 & 49 & 03 & & 60 & & 39 & & 24 & 3,10 & 07 & 14 & 0,12 & 06 & & 69 & & 1,7 \\
\hline & & & 20 & & & & & & 6 & & & & & & & & & 63 \\
\hline & & & & & & & & & & & & & & & & 56 & & 43 \\
\hline & 73 & 34 & 01 & 58 & 8 & & & & 4 & 1,25 & - & & 0,09 & 3 & 0,02 & ,15 & & 3,8 \\
\hline $\mathbf{N}$ & 37 & 35 & 01 & 2 & & & & & 5 & 0 & 2,05 & 0,21 & 04 & 1 & $-0,01$ & 94 & 0 & 4,8 \\
\hline & & $z$ & & & & & & & & & & & & & & & & 1 \\
\hline II & 59 & 46 & 01 & $-0,01$ & 08 & 86 & & & 34 & 1,9 &, 71 & & $-0,03$ & $-0,03$ & $-0,02$ & ),80 & & 73,1 \\
\hline M & 39 & 34 & 00 & 19,1 & 9 & 19 & 0 & & 0,86 & 0,16 & 0,33 & 0,69 & 0,00 & -0 & 0,00 & 0,95 & 0 & 72,1 \\
\hline & & 8 & 6 & & & & & & 72 & 0 & 04 & & & & & 2,03 & & 2,2 \\
\hline & 76 & 17 & 05 & 1,59 & 2 & & & & 47 & 1,12 & 1,50 & 0 & $-0,26$ & $-0,12$ & $-0,06$ & $-0,12$ &, 00 & 112 \\
\hline $\mathrm{K}$ & 04 & 59 & 02 & 2,20 & & & & & & 1, & 1, & 0,2 & $-0,05$ & & $-0,03$ & 0,45 & 0 & 43,3 \\
\hline & & 71 & 08 & 36 & 8 & & 9 & & 0,80 & 0,24 & 2,46 & 47 & 0,07 & 9 & ,06 & 1,28 & 00 & 81,7 \\
\hline & 1,29 & 0,66 & 02 & & & & & & 0,43 & 1 , & 1,01 & & 0,10 & & 0,09 & 59 & 01 & 85,6 \\
\hline & 9 & 0,78 & & & & & & & & 1,26 & & & & & 0 & 1,04 & & 62,5 \\
\hline RS & 8 & 53 & 08 & 1,41 & 7 & 2 & 2 & 7 & 0,71 & 0,41 & 1,79 & 1 & 6 & 5 & 04 & 49 & 00 & 59,8 \\
\hline RG & 1,69 & 0,81 & 21 & 89 & 98 & & & & & 0,73 & 0,65 & & & & 0,00 & 1,05 & 01 & 2,1 \\
\hline 1 AS & 0,82 & $0,4 J$ & & & J,00 & & & & & 0,19 & 0 & & $-0,11$ & 0,39 & $-0,06$ & 0,59 & 0,01 & 85,3 \\
\hline & 4,34 & 2,65 & 21 & 17 & 3,25 & & & & & &, 86 & & & & 0,10 & & 00 & 214 \\
\hline AS & 1,26 & 0,69 & 16 & 1,46 & & 3,6 & 1, & & 0,56 & 0,77 & 1,13 & 0,40 & 0,17 & 0,59 & 0,26 & 7,47 & 01 & 253 \\
\hline UNSA & 1,01 & 59 & 07 & 2,24 & 4,01 & 25 & 1,21 & 4,55 & 0,73 & 0,36 & 1,17 & 0,68 & 0,07 & 0,31 & 0,08 & 1,70 & 0,01 & 153 \\
\hline
\end{tabular}

En iyi kriter ile en kötü kriter değerleri bulunarak matris

normalleştirilmiş ve tablo 10'da sunulmuştur.

Tablo 10. Normalleștirilmiș Matris.

\begin{tabular}{|c|c|c|c|c|c|c|c|c|c|c|c|c|c|c|c|c|c|c|}
\hline 2017 & $\mathrm{CO}$ & LO & NO & SBO & ALD & $\overline{\mathrm{DH}}$ & KD & OZD & KO & FO & YO & $\mathbf{K}$ & $\mathbf{K}$ & $\mathrm{OK}$ & K & $\overline{\mathbf{O}}$ & K & PDD \\
\hline En iyi & 4,34 & 65 & 01 & & 23 & .72 & 47 & 09 & & 8,4 & 2 & 04 & 0,30 & 59 &, 26 & 77,4 & 38 & 52,8 \\
\hline & 37 & 7 & & & 0,89 & & & & & & & & 0,26 & & & 12 & & \\
\hline $\mathbf{S}$ & 76 & 87 & & & 55 & & & & 23 & & & & & & 56 & 99 & 95 & 76 \\
\hline & 81 & & & & 37 & & & & 37 & & & TL & $\pi$ & & &, 99 & 00 & 00 \\
\hline & 60 & 43 & 98 & 06 & 0,96 & & 0 & & 0,43 & 3 & 0 & 0,26 & 0,35 & 0,50 & & 00 &, 11 &, 00 \\
\hline & 91 & & & & & & & & & & & & & & & & ,98 & 87 \\
\hline & 00 & 93 & & 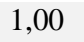 & & & & & 0,60 & 6 & & &, 60 & & & 1,00 & 98 &, 75 \\
\hline 3 & 84 & 82 & & ,06 & 0,88 & & & & 1,00 & 1,00 & 0,00 & 0,55 & 0,50 & 0,46 & 0 & 1,00 & 0,97 & 0,24 \\
\hline & 19 & & & 00 & & & & & & & & & 0 & & & 0 & &, 71 \\
\hline & 74 & 53 & 0 & 45 & 00 & & & & 0,97 & 0 & 0 & & 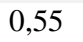 & 3 & 1 & 1,00 & 98 &, 72 \\
\hline &, 81 & 1,0 & 95 &, 02 & 0,28 & & & & 0,80 & 0,99 & 0 , & 0,90 & 0,36 & 0,31 & 0,55 & 1,00 & 0,97 & 0,72 \\
\hline & 90 & & & ( & & & & & & & & 0, & $1,($ & & & 1,00 & & 0,56 \\
\hline EK & 83 & 83 & & 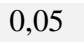 & 0,83 & & & 0,89 & 0,36 & 1 & ? & 8 & 0,62 & 65 & 39 & 1,00 & 99 &, 83 \\
\hline & 0,82 & 0,78 & & 0,06 & 0,89 & & & & 0,90 & 0,99 & & 0,67 & 0,41 & 0,31 & 0,62 & 1,00 & 0,97 & 0,68 \\
\hline & 77 & & & 0,04 & & & & & & & & & 0 , & & & 0,99 & 14 & 0,66 \\
\hline & .77 & & & 44 & 0 & & & 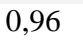 & 7 & & 30 & 26 & 0,52 & 60 & 9 & 1,00 & 98 & 0,75 \\
\hline & 0,80 & & & 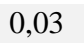 & & & & & 0, & & & & 0,43 & & & 1,00 & ,97 & 0,76 \\
\hline RG & 67 & & & 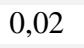 & & & & & 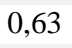 & & & 0 & 3 & & 0,79 & 1,00 & 5 & 0,99 \\
\hline & 0,89 & & &, 06 & 0,79 & & & & 0,95 & 1,00 & 0,12 & 0,42 & 0,74 & 1,00 & 0,99 & 1,00 & 00 & 0,66 \\
\hline &, 00 & & & & & & & & 0, & 0,00 & 0 & & 0,00 & 0,50 & 0,50 & 0,00 &, 97 & 0,15 \\
\hline & 0,78 & & & & & & & & & & & & 0,23 & & & 0,98 & 0,95 & 0,00 \\
\hline UNSA & 0,84 & 83 & 94 & 0,05 & 0,86 & 0,91 & 0,20 & 0,27 & 0,82 & 0,99 & 0,83 & 0,99 & 0,42 & 0,29 & 0,54 & 1,00 & 0,96 & 0,40 \\
\hline
\end{tabular}

Normalize edilmiş karar matrisinin her bir sütun elemanı AHP yöntemi ile elde edilmiş öncelikler vektörü $(\boldsymbol{w})$ ile teker teker çarpılarak matris ağırlıklandırılmış ve tablo 11'de sunulmuştur. 
Tablo 11. Ağırlıklandırılmış Matris.

\begin{tabular}{|c|c|c|c|c|c|c|c|c|c|c|c|c|c|c|c|c|c|c|}
\hline & $\overline{\mathbf{O}}$ & $\mathbf{O}$ & NO & & & & & & & & & & & & K & KC & $\overline{\text { BI }}$ & PDI \\
\hline$w$ & & 03 &, 04 & 01 & ,05 & $\overline{04}$ & 02 & & & 0,03 & 0,03 & & 18 & 10 & 10 & $\overline{0,03}$ &, 09 & \\
\hline$\overline{\Gamma \mathbf{T H}}$ & 03 & 03 & 04 & 00 & 03 & 0,04 & 0,02 & 3 & 00 & 02 & $\overline{02}$ & & J6 & 56 & 06 & 03 & $\overline{09}$ & 10 \\
\hline & 03 & 02 & 03 & & & & & & & & 02 & & & & & & &, 13 \\
\hline & & & & & 05 & & & & & & & & & & & & & \\
\hline & 03 & 03 & 04 & 00 & 05 & 04 & 02 & 3 & 01 & 03 & 02 & ,01 & 07 & 06 & 0,07 & 0,03 &, 05 & 11 \\
\hline & & 03 & 04 & 01 & 05 & 0,00 & 0,02 & & 0,01 & 0,03 & 02 & 01 & & 96 &, 08 &, 03 &, 05 &, 10 \\
\hline & & & & & & & & & & & & & & & & & & \\
\hline & 01 & 00 & 00 & 00 & 0,05 & 0,04 & 0,01 & ,03 & 0,01 & 0,02 & 0,03 & 0,00 & 0,11 & 0,07 & 0,08 & 0,03 & ,09 & 0,09 \\
\hline & & & & & 05 & & & & & & & & & & 0,08 & 0,03 & & \\
\hline & & 03 & 04 & 00 & 01 & ,04 & D1 & 02 & 02 &, 03 & , 02 & 02 & 07 & 03 & 05 & ,,03 & 09 & ,, 09 \\
\hline & & & 04 & 00 & 00 & 0,04 & 02 & & 0,01 & 03 & 02 & 01 & & 8 & 10 & 0,03 & 09 & 0,07 \\
\hline & & 03 & 04 & 00 & ,04 & 0,03 & 0,0 & & 0,01 & 0,02 & ,, 02 & ,0 &, 12 & 07 & 0,08 & 0,03 & , & 0 , \\
\hline & 03 & 02 & 4 & 0,00 & 15 & 0,03 & 0,01 & 0,01 &, 02 & 03 & 02 & 02 & 0,08 & 3 & 06 & ,03 & 0,09 &, 09 \\
\hline & & & $0, \mathrm{c}$ & 0 & 0,0 & 0, & 0, & & & & 0,02 & 0,01 & & & 0,05 & 03 & ,09 & 0,09 \\
\hline & 0,03 & 02 & 0,04 & 0,00 & 0,05 & 0, & 0,02 & 0,03 & 0,0 & 0.0 & 0,02 & 0,01 & 0,10 & 6 & 0,08 & 0,03 &, 0 & 0,10 \\
\hline & 0,03 & 03 &, 04 & 0,00 & 0,03 & 0,04 & 0,01 & 0,02 & 0,02 & 0,03 & 0,02 & 0,01 & 0,08 &, 05 & 0,06 & 0,03 & 0,09 & 0,10 \\
\hline & 02 & 02 & 0,03 & 0,00 & 0,0 & 0,0 & 0, & & 0,0 & 0 , & 0, & 0,01 & 0,10 & ,06 & 0,08 & 0,03 & 0,0 & 0 . \\
\hline & 03 & 03 & 04 & ,00 & 04 & 0,04 & 0,0 & & 0, & 0,0 & 0,0 & 0,0 & & & 0,09 & 03 & 0,09 & 0,0 \\
\hline & 0,00 & ,00 & 0,03 & 0,0 & 0,05 & 0,03 & 0,0 & 0,03 & 0,00 & 0,00 & 0,02 & 0,00 & 0,00 & 0,05 & 0,05 & 0,00 & 0,09 & 0,02 \\
\hline & 0,0 & ,02 & 0,0 & 0,0 & 0,03 & 0,0 & 0, & 0, & $0,($ & 0, & 0, & $0, \mathrm{C}$ & & 0,00 & 0,00 & 0,03 & 0,0 & 0,0 \\
\hline NSA & 0,03 & 03 & 04 & 00 & 05 & 0,03 & 0,00 & 0,01 & 0,02 & 0,03 & 0,02 & 0,02 & 0,08 & 0,03 & 0,05 & 0,03 & 0,09 & 0,05 \\
\hline
\end{tabular}

Her bir alternatif için ortalama ve en iyi grup skorları için (7, 8 ve 9) nolu formüller kullanılarak hesaplamalar yapılmıştır. DQ değeri 0,053 bulunmuştur. Bu durumda grup faydası stratejik ağırlık oranını $(v=0,0, v=0,25, v=0,5, v=0,75$ ve $v=1,0)$ beş farklı seviyede kabul ederek $S_{i}, R_{i}$ ve $Q_{i}$ değerleri hesaplanarak ve siralanarak tablo 12 'de sunulmuştur. Maksimum grup faydası stratejik ağırlığının $v>0,5$ olması istenir. Büyük olması durumunda anlaşma sağlanmış, düşük olması durumunda ise anlaşma sağlanmamış olur (Opricovic, 2004:448).

Tablo 12. Farklı Seviyelerde Maksimum Grup Faydası Stratejik Ağırlı̆̆ına Göre Si,Ri ve Qi Değerleri ve Sıralamaları.

\begin{tabular}{|c|c|c|c|c|c|c|c|c|c|c|c|c|c|c|}
\hline & \multirow[b]{2}{*}{$S_{i}$} & \multirow[b]{2}{*}{ Sira } & \multirow[b]{2}{*}{$\boldsymbol{R}_{i}$} & \multirow[b]{2}{*}{ Sira } & \multicolumn{2}{|c|}{$\boldsymbol{v}=0,00$} & \multicolumn{2}{|c|}{$v=0,25$} & \multicolumn{2}{|c|}{$v=0,50$} & \multicolumn{2}{|c|}{$\boldsymbol{v}=0,75$} & \multicolumn{2}{|c|}{$\boldsymbol{v}=1,00$} \\
\hline & & & & & $Q_{i}$ & Sira & $Q_{i}$ & Sira & $Q_{i}$ & Sira & $Q_{i}$ & Sira & $Q_{i}$ & Sira \\
\hline ATEKS & 0,66 & 10 & 0,10 & 9 & 0,14 & 9 & 0,26 & 8 & 0,39 & 8 & 0,52 & 10 & 0,64 & 10 \\
\hline ARSAN & 0,58 & 3 & 0,13 & 17 & 0,47 & 17 & 0,46 & 16 & 0,45 & 10 & 0,44 & 5 & 0,43 & 3 \\
\hline BLCYT & 0,61 & 6 & 0,13 & 18 & 0,47 & 18 & 0,48 & 17 & 0,49 & 14 & 0,51 & 9 & 0,52 & 6 \\
\hline BRKO & 0,75 & 15 & 0,11 & 14 & 0,29 & 14 & 0,43 & 14 & 0,56 & 16 & 0,70 & 15 & 0,84 & 15 \\
\hline BRMEN & 0,75 & 16 & 0,11 & 13 & 0,25 & 13 & 0,40 & 13 & 0,55 & 15 & 0,71 & 16 & 0,86 & 16 \\
\hline BOSSA & 0,61 & 5 & 0,09 & 6 & 0,05 & 6 & 0,17 & 5 & 0,28 & 4 & 0,40 & 4 & 0,51 & 5 \\
\hline DAGI & 0,67 & 11 & 0,11 & 12 & 0,25 & 12 & 0,35 & 12 & 0,45 & 11 & 0,56 & 12 & 0,66 & 11 \\
\hline DERIM & 0,73 & 13 & 0,10 & 10 & 0,15 & 10 & 0,31 & 11 & 0,47 & 12 & 0,63 & 13 & 0,80 & 13 \\
\hline DESA & 0,63 & 7 & 0,09 & 7 & 0,08 & 7 & 0,20 & 7 & 0,32 & 7 & 0,44 & 7 & 0,57 & 7 \\
\hline DIRIT & 0,80 & 19 & 0,18 & 20 & 1,00 & 20 & 1,00 & 20 & 0,99 & 20 & 0,99 & 20 & 0,98 & 19 \\
\hline НАТЕК & 0,78 & 18 & 0,12 & 15 & 0,29 & 15 & 0,45 & 15 & 0,60 & 17 & 0,76 & 17 & 0,92 & 18 \\
\hline KRTEK & 0,65 & 9 & 0,09 & 5 & 0,03 & 5 & 0,17 & 6 & 0,32 & 6 & 0,46 & 8 & 0,60 & 9 \\
\hline KORDS & 0,64 & 8 & 0,09 & 3 & 0,01 & 3 & 0,15 & 4 & 0,30 & 5 & 0,44 & 6 & 0,58 & 8 \\
\hline LUKSK & 0,74 & 14 & 0,10 & 8 & 0,13 & 8 & 0,30 & 10 & 0,47 & 13 & 0,65 & 14 & 0,82 & 14 \\
\hline MNDRS & 0,68 & 12 & 0,10 & 11 & 0,15 & 11 & 0,28 & 9 & 0,41 & 9 & 0,54 & 11 & 0,67 & 12 \\
\hline RODRG & 0,77 & 17 & 0,13 & 16 & 0,46 & 16 & 0,56 & 18 & 0,67 & 18 & 0,78 & 18 & 0,89 & 17 \\
\hline SKTAS & 0,81 & 20 & 0,14 & 19 & 0,51 & 19 & 0,63 & 19 & 0,76 & 19 & 0,88 & 19 & 1,00 & 20 \\
\hline
\end{tabular}




\begin{tabular}{|c|c|c|c|c|c|c|c|c|c|c|c|c|c|c|}
\hline SNPAM & 0,40 & 2 & 0,09 & 4 & 0,02 & 4 & 0,01 & 2 & 0,01 & 2 & 0,01 & 2 & 0,00 & 2 \\
\hline YATAS & 0,40 & 1 & 0,09 & 1 & 0,00 & 1 & 0,00 & 1 & 0,00 & 1 & 0,00 & 1 & 0,00 & 1 \\
\hline YUNSA & 0,61 & 4 & 0,09 & 2 & 0,01 & 2 & 0,13 & 3 & 0,26 & 3 & 0,38 & 3 & 0,51 & 4 \\
\hline$S^{*}$ min & 0,397 & & S- me & & $\mathbf{0 , 8 1 2}$ & & $\mathbf{R}^{*} \mathbf{m}$ & & 0,087 & & R-n & & 0,184 & \\
\hline
\end{tabular}

Siralanan alternatiflerin doğruluğu farklı seviyedeki grup faydası stratejik ağırlığına göre test edildiğinde çoğunlukla 1. Koşulun sağlanmadığ1 ancak 2. koşulun sağlandiğ 1 görülmektedir. Bu durum diğer yıllar için yapıldığında ise, kısmen sağlandığı görülmüştür. Yıllar itibariyle farklı seviyedeki grup faydası stratejik ağırlığına göre test sonuçları tablo 13'te gösterilmiştir.

Tablo 13. Y1llar İtibariyle Farklı Seviyedeki Maksimum Grup Faydası Stratejik Ağırlı̆̆ına Göre Test Sonuçları.

\begin{tabular}{|c|c|c|c|c|c|c|c|}
\hline & & & $v=0,00$ & $v=0,25$ & $v=\mathbf{0 , 5 0}$ & $v=0,75$ & $v=1,00$ \\
\hline \multirow{4}{*}{2017} & \multirow{2}{*}{\multicolumn{2}{|c|}{ Koşul 1}} & $0,006>0,053$ & $0,015>0,053$ & $0,011>0,053$ & $0,007>0,053$ & $0,003>0,053$ \\
\hline & & & Sağlanamamış & Sağlanamamış & Sağlanamamış & Sağlanamamış & Sağlanamamış \\
\hline & \multirow{2}{*}{ Koşul 2} & $S_{i}$ & $0<0,397$ & $0<0,397$ & $0<0,397$ & $0<0,397$ & $0<0,397$ \\
\hline & & $R_{i}$ & $0<0,087$ & $0<0,087$ & $0<0,087$ & $0<0,087$ & $0<0,087$ \\
\hline \multirow{4}{*}{2016} & \multirow{2}{*}{\multicolumn{2}{|c|}{ Koşul 1}} & $0,048>0,053$ & $0,014>0,053$ & $0,077>0,053$ & $0,092>0,053$ & $0,048>0,053$ \\
\hline & & & Sağlanamamış & Sağlanamamış & SNPAM & SNPAM & Sağlanamamış \\
\hline & \multirow{2}{*}{ Koşul 2} & $S_{i}$ & $0<0,465$ & $0,036<0,465$ & $0,024<0,465$ & $0,012<0,465$ & $0<0,465$ \\
\hline & & $R_{i}$ & $0<0,078$ & $0,036<0,078$ & $0,024<0,078$ & $0,012<0,078$ & $0<0,078$ \\
\hline \multirow{4}{*}{2015} & \multirow{2}{*}{\multicolumn{2}{|c|}{ Koşul 1}} & $0,319>0,053$ & $0,304>0,053$ & $0,199>0,053$ & $0,094>0,053$ & $0,012>0,053$ \\
\hline & & & BRMEN & BRMEN & BRMEN & BRMEN & Sağlanamamış \\
\hline & \multirow{2}{*}{ Koşul 2} & $S_{i}$ & $0<0,530$ & $0,003<0,530$ & $0,006<0,530$ & $0,009<0,530$ & $0<0,530$ \\
\hline & & $R_{i}$ & $0<0,107$ & $0,003<0,107$ & $0,006<0,107$ & $0,009<0,107$ & $0<0,107$ \\
\hline \multirow{4}{*}{2014} & \multirow{2}{*}{\multicolumn{2}{|c|}{ Koşul 1}} & $0,038>0,053$ & $0,062>0,053$ & $0,087>0,053$ & $0,112>0,053$ & $0,136>0,053$ \\
\hline & & & Sağlanamamış & SNPAM & SNPAM & SNPAM & SNPAM \\
\hline & \multirow{2}{*}{ Koşul 2} & $S_{i}$ & $0<0,412$ & $0<0,412$ & $0<0,412$ & $0<0,412$ & $0<0,412$ \\
\hline & & $R_{i}$ & $0<0,091$ & $0<0,091$ & $0<0,091$ & $0<0,091$ & $0<0,091$ \\
\hline
\end{tabular}

Yıllar itibariyle farklı seviyedeki grup faydasına göre, koşul

2 sağlandığına göre koşul 1 için uzlaşık çözüm sağlanamayan durumlara ait gerekli hesaplamalar (12) nolu formül kullanılarak yapılmış ve tablo 14 'te gösterilmiştir.

Tablo 14. Yıllar İtibariyle Farklı Seviyedeki Grup Faydası Stratejik Ağırlığına Göre Koşul 1 İçin Uzlaşık Çözümler.

\begin{tabular}{|c|c|c|c|c|c|c|c|c|c|c|c|c|c|c|c|}
\hline & \multicolumn{4}{|c|}{$v=0,00$} & \multicolumn{2}{|c|}{$v=0,25$} & \multicolumn{3}{|c|}{$v=\mathbf{0 , 5 0}$} & \multicolumn{3}{|c|}{$v=0,75$} & \multicolumn{3}{|c|}{$v=1,00$} \\
\hline \multirow{6}{*}{2017} & 1 & BOSSA & 0,001 & 1 & SNPAM & 0,038 & 1 & SNPAM & 0,042 & 1 & SNPAM & 0,046 & 1 & SNPAM & 0,050 \\
\hline & 2 & KRTEK & 0,023 & 2 & YATAS & 0,053 & 2 & YATAS & 0,053 & 2 & YATAS & 0,053 & 2 & YATAS & 0,053 \\
\hline & 3 & SNPAM & 0,034 & & & & & & & & & & & & \\
\hline & 4 & KORDS & 0,044 & & & & & & & & & & & & \\
\hline & 5 & YUNSA & 0,047 & & & & & & & & & & & & \\
\hline & 6 & YATAS & 0,053 & & & & & & & & & & & & \\
\hline \multirow{2}{*}{2016} & 1 & SNPAM & 0,005 & 1 & DAGI & 0,038 & & & & & & & 1 & HATEK & 0,004 \\
\hline & 2 & DAGI & 0,053 & 2 & SNPAM & 0,053 & & & & & & & 2 & SNPAM & 0,053 \\
\hline \multirow{2}{*}{2015} & & & & & & & & & & & & & & BRMEN & 0,041 \\
\hline & & & & & & & & & & & & & 2 & SNPAM & 0,053 \\
\hline 2014 & 1 & SNPAM & 0,053 & & & & & & & & & & & & \\
\hline
\end{tabular}

Sonuç olarak, 2017 yılında $\mathrm{v}=0,0$ grup faydası stratejik ağırlığına göre BOSSA, KRTEK, SNPAM, KORDS, YUNSA ve YATAS işletmeleri birlikte en iyi performansı sağlayan işletmeler olmuştur. Grup faydası stratejik ağırlığı $\mathrm{v}=0,25, \mathrm{v}=0,5, \mathrm{v}=0,75$ ve $\mathrm{v}=1,0$ göre SNPAM ve YATAS işletmeleri en iyi performansı sağlayan işletmeler olmuştur.

2016 yılında, grup faydası stratejik ağırlık v=0,5 ve $\mathrm{v}=0,75$ göre SNPAM her iki koşulu da sağlayarak en iyi performansı sağlayan işletme olmuştur. Grup faydası stratejik ağırlık $\mathrm{v}=0,0, \mathrm{v}=0,25$ ve $\mathrm{v}=1,0$ göre koşul 1 sağlanamadığından $\mathrm{v}=0,0$ için; SNPAM ve DAGI, $\mathrm{v}=0,25$ için; DAGI ve
SNPAM, v=1,0 için; HATEK ve SNPAM birlikte en iyi performansı sağlayan işletmeler olmuştur.

2015 yılında, grup faydası stratejik ağırlık v=0,0, v=0,25, $\mathrm{v}=0,5$ ve $\mathrm{v}=0,75$ göre $\mathrm{BRMEN}$ her iki koşulu da sağlayarak en iyi performansı sağlayan işletme olmuştur. Grup faydası stratejik ağırlık v=1,0 göre BRMEN ve SNPAM birlikte en iyi performansı sağlayan işletmeler olmuştur.

2014 yılında, grup faydası stratejik ağırlık, v=0,25, v=0,5 $\mathrm{v}=0,75$ ve $\mathrm{v}=1,0$ göre SNPAM her iki koşulu da sağlayarak en iyi performansı sağlayan işletme olmuştur. Grup faydası stratejik ağırlık $v=0,0$ göre koşul $1^{\prime} i$ daha önce 
sağlanmamasına rağmen SNPAM yine tek başına en iyi performansı sağlayan işletme olmuştur.

\section{Sonuç}

$\mathrm{Bu}$ çalışmada, BİST'te dokuma, giyim eşyası ve deri sektöründeki bütün işletmelerin 2014-2017 yıllarına ait çok kriterli karar verme yöntemlerinden AHP ve VIKOR yöntemi kullanılarak finansal performans analizi yapılmıştır. AHP ve VİKOR yönteminde kullanılan kriterler, finansal oranlardır. Çalışmada kullanılan finansal oranlar kamuyu aydınlatma platformundan BİST'te dokuma, giyim eşyası ve deri işletmelerinin 2014-2017 yıllarına ait bilanço ve gelir tablosu bilgilerinden sağlanıştır.

VİKOR yönteminin sübjektif olan en hassas noktasını kriter ağırlıklılarının belirlenmesi aşaması oluşturmaktadır. Kriter ağırlıklılarının belirlenmesinde AHP yöntemi kullanarak daha objektif olması sağlanmıştır. AHP yöntemindeki en hassas nokta, kriter ağırlıklarının kabul edilebilir sınırlar içerisinde olup olmadığıdır. Bunun içinde tutarlılık testi yapılarak bu hassas nokta aşılmıştır.

Çalışmada ilk önce, AHP yöntemi ile finansal oranların ağırlıklarının belirlenmesi ve sıralaması yapılmıştır. AHP ile bulunan oran sıralamasında, ilk sırayı satışların karlılığ almıştır. Piyasa Değeri / Defter Değeri Oranı ikinci sırayı almıştır. Stok Bağımlılık Oranı ise en son sırada yer almıştır.

Çalışmanın ikinci aşamasını VİKOR yöntemi ile BİST'te dokuma, giyim eşyası ve deri işletmelerinde 2014-2017 yıllarına ait farklı seviyedeki grup faydası stratejik ağırlığına göre finansal performans hesaplaması yapılmıştır.

2017 yılında farklı seviyedeki grup faydası stratejik ağırlığına göre uzlaşık çözüm genelde SNPAM ve YATAS işletmeleri arasında gerçekleşmiştir.

2016 yılında farklı seviyedeki grup faydası stratejik ağırlığına göre uzlaşık çözümde genelde SNPAM işletmesi yer almıştır.

2015 yılında farklı seviyedeki grup faydası stratejik ağırlığına göre uzlaşık çözümde genelde BRMEN işletmesi yer almıştır.

2014 yılında farklı seviyedeki grup faydası stratejik ağırlığına göre uzlaşık çözümde genelde SNPAM işletmesi yer almıştır.

Genel olarak 2014-17 y1lları itibariyle, SNPAM en iyi finansal performansı sağlayan işletmedir denilebilir. SNPAM işletmesinin fiili finansal oranlarına bakıldığında, AHP yöntemiyle belirlenmiş sıralamada en ilk sırada yer alan satışların karlılığının diğer işletmelerden en yükseği olduğu görülmektedir. Literatür taramasında yapılan inceleme sonucunda genel olarak AHP, VİKOR, TOPSİS ve ELECTRE gibi yöntemlerle yapılan sırlamalar değişmemiş olup, bu çalışmada da AHP ve VİKOR yöntemiyle yapılan sıralama yaklaşık olarak değişmemiştir. Yani, AHP ve VİKOR ile yapılan analiz sonucu ile aynı doğrultuda olması, yöntemlerin kullanılabilir olduğunu ve yönlendirici olduğunu göstermektedir.

Analizde yer alan işletme sahip ve yöneticilerine finansal performansları hakkında bilgi sağlamış olmasının yanında potansiyel yatırımcılara da karar süreçlerinde fayda sağlayacağı düşünülmektedir.
Daha özel veya daha genel sonuçlar için kullanılan oran sayıları artırılabilir veya azaltılabilir. Sektör deki daha fazla işletme analize eklenerek karşılaştırma yapılabileceği gibi işletmenin kendine rakip gördüğü işletmeleri kapsayacak daha dar dairede de yapılarak çok özel sonuçlar elde edilebilir.

\section{Kaynakça}

Abastante, F., Corrente, S., Greco, S., Ishizaka, A., \& Lami, I. M. (2019). A New Parsimonious AHP Methodology: Assigning Priorities to Many Objects by Comparing Pairwise Few Reference Objects. Expert Systems with Applications, 109-120.

Akkaya, G. C., \& Demireli, E. (2010). Analitik Hiyerarşi Süreci ile Kredi Derecelendirme Analizi Üzerine Bir Model Önerisi. Journal of the Cukurova University Institute of Social Sciences, 19(1). 319-335.

Akyüz, G. A. (2012). Bulanık VIKOR Yöntemi ile Tedarikçi Seçimi. Atatürk Üniversitesi Iktisadi ve İdari Bilimler Dergisi, 26(1), 197-215.

Alonso, J. A., \& Lamata, M. T. (2006). Consistency in The Analytic Hierarchy Process: A New Approach. International Journal of Uncertainty, Fuzziness And Knowledge-Based Systems, 14(04), 445459.

Apan, M., Öztel, A., \& İslamoğlu, M. (2018). Comparative Empirical Analysis of Financial Failures of Enterprises with Altman Z-Score and VIKOR Methods: BIST Food Sector Application. Australasian Accounting, Business and Finance Journal, 12(1), 77-101.

Ar, İ. M., Baki, B., \& Özdemir, F. (2014). Kuruluş Yeri Seçiminde Bulanık AHS-VIKOR Yaklaşımının Kullanımı: Otel Sektöründe Bir Uygulama. International Journal of Economic \& Administrative Studies, 7(13). 1307-9832.

Bana e Costa, C. A., Van Snick, J.-C., (2008). A Critical Analysis of The Eigen Value Method Used to Derive Priorities in AHP. European Journal of Operational Research, 187(3), 1422-1428.

Bayrakdaroglu, A., \& Yalçin, N. (2012). Strategic Financial Performance Evaluation of The Turkish Companies Traded on ISE/IMKB'de Islem Gören Türk Sirketlerinin Stratejik Finansal Performans Değerlendirmesi. Ege Akademik Bakls, 12(4), 529-539.

Chang, S. C., \& Tsai, P. H. (2016). A Hybrid Financial Performance Evaluation Model for Wealth Management Banks Following The Global Financial Crisis. Technological and Economic Development of Economy, 22(1), 21-46. Doi:10.3846/20294913.2014.986771.

Çakır, E, \& Özdemir, M. (2016). Bulanık Çok Kriterli Karar Verme Yöntemlerinin Altı Sigma Projeleri Seçiminde Uygulanmas1. Business and Economics Research Journal, 7(2), 167-201.

Çetiner, E. (1996). İşletmelerde Mali Analiz. Gazi Kitabevi, Ankara. 
Dinçer, H., \& Görener, A. (2011). Analitik Hiyerarşi Süreci ve VİKOR Tekniği ile Dinamik Performans Analizi: Bankacılık Sektöründe Bir Uygulama. Istanbul Ticaret Üniversitesi Sosyal Bilimler Dergisi, Y11:10 Say1:19 Bahar 2011, 109-127.

Dinçer, H., \& Görener, A. (2011). Performance Evaluation Using AHP-VIKOR and AHP-TOPSIS Approaches: The Case of Service Sector. Sigma Journal of Engineering and Natural Sciences, 29(3), 244-260.

Esbouei, S. K., Ghadikolaei, A. S., \& Antucheviciene, J. (2014). Using FANP and Fuzzy VIKOR for Ranking Manufacturing Companies Based on Their Financial Performance. Economic Computation \& Economic Cybernetics Studies \& Research, 48(3), 141-162.

Franek, J., \& Kresta, A. (2014). Judgment Scales and Consistency Measure in AHP. Procedia Economics and Finance, 12, 164-173.

Gök-Kısa, A. C., \& Perçin, S. (2018). Bütünleşik Entropi Ağırlık-VIKOR Yöntemi ile Bilişim Teknolojisi Sektöründe Performans Ölçümü. Ekonomik ve Sosyal Araştırmalar Dergisi, Cilt 14, Y11 14, Say1 1, 2018.

Göksu, A., \& Güngör, İ. (2008). Bulanık Analitik Hiyerarşik Proses ve Üniversite Tercih Siralamasinda Uygulanmas1. Süleyman Demirel Üniversitesi İktisadi ve İdari Bilimler Fakültesi Dergisi, 13(3), 1-26.

Göktolga, Z. G., \& Karakış, E. Bireysel Emeklilik Şirketlerinin Finansal Performanslarının Bulanık AHP ve VIKOR Yöntemi ile Analizi. Cumhuriyet Üniversitesi Iktisadi ve İdari Bilimler Dergisi, 18(1), 92-108.

Gönenli, A. (1979). Finansal Tablolar: Analiz ve Yorum. Sermet Matbaast, İstanbul.

Ishizaka, A., \& Labib, A. (2011). Review of The Main Developments in The Analytic Hierarchy Process. Expert Systems with Applications, 38(11), 14336-14345.

İç, Y. T., Tekin, M., Pamukoğlu, F. Z., \& Yıldırım, S. E. (2015). Kurumsal Firmalar İçin Bir Finansal Performans Karşıllaştırma Modelinin Geliştirilmesi. Gazi Üniversitesi Mühendislik-Mimarlık Fakültesi Dergisi, 30(1), 71-85.

Karaoğlan, S., \& Şahin, S. (2018). BİST XKMYA İşletmelerinin Finansal Performanslarının Çok Kriterli Karar Verme Yöntemleri ile Ölçümü ve Yöntemlerin Karşılaştırılması. Ege Academic Review, 18(1).63 / 80, Doi: 10.21121/Eab.2018135912.

Krejčí, J., \& Stoklasa, J. (2018). Aggregation in The Analytic Hierarchy Process: Why Weighted Geometric Mean Should Be Used İnstead of Weighted Arithmetic Mean. Expert Systems with Applications, 114, 97-106.

Kuruüzüm, A., \& Atsan, N. (2001). Analitik Hiyerarşi Yöntemi ve İşletmecilik Alanındaki Uygulamaları. Akdeniz University Faculty of Economics \& Administrative Sciences Faculty Journal/Akdeniz Universitesi Iktisadi ve Idari Bilimler Fakultesi Dergisi, 1(1), 83-105.
Kuzu S. (2015) “VIKOR”. İçinde: B. F. Yıldırım, E. Önder (Ed.). Operasyonel, Yönetsel ve Stratejik Problemlerin Çözümünde Çok Kriterli Karar Verme Yöntemleri. (s.117-132) Dora Basım-Yayın Dă̆ıtım Ltd. Şti., Bursa.

Maya, Rıdvan, \& Eren, Tamer, Türk Gıda Sektörünün Finansal Performans Analizinin Çok Kriterli Karar Verme Yöntemleri ile Yapılması. Verimlilik Dergisi, (2018/3), 31-60.

Opricovic S. \& Tzeng G. (2002) Compromise solution by MCDM methods: A comparative analysis of VIKOR and TOPSIS. European Journal of Operational Research, 156 (2004) 445-455.

Ömürbek, N., Karaatlı, M., \& Yetim, T. (2014). Analitik Hiyerarşi Sürecine Dayalı TOPSIS ve VIKOR Yöntemleri ile ADIM Üniversitelerinin Değerlendirilmesi. Selçuk Üniversitesi Sosyal Bilimler Enstitüsü Dergisi, 189-207.

Önder G., \& Önder A. (2015). “Analitik Hiyerarşi Süreci”. İçinde: B. F. Yıldırım, E. Önder (Ed.). Operasyonel, Yönetsel ve Stratejik Problemlerin Çözümünde Çok Kriterli Karar Verme Yöntemleri. (s.21-74) Dora Basım-Yayın Dă̆ıtım Ltd. Şti., Bursa.

Rezaie, K., Ramiyani, S. S., Nazari-Shirkouhi, S., \& Badizadeh, A. (2014). Evaluating Performance of Iranian Cement Firms Using an İntegrated Fuzzy AHP_ VIKOR Method. Applied Mathematical Modelling, 38(21-22), 5033-5046.

Tezergil, Seher A. (2016). Vikor Yöntemi ile Türk Bankacılık Sektörünün Performans Analizi. Marmara Üniversitesi İktisadi ve İdari Bilimler Dergisi, Cilt 38, Say1 1, Haziran 2016, Issn: 2149-1844, 357-373, Doi: 10.14780/İ̈BF.92056.

Turan, G. (2015) “Çok Kriterli Karar Verme”. İçinde: B. F. Y1ldırım, E. Önder (Ed.). Operasyonel, Yönetsel ve Stratejik Problemlerin Çözümünde Çok Kriterli Karar Verme Yöntemleri. (s.15-20). Dora Basım-Yayın Dağıtım Ltd. Şti., Bursa.

Wind, Y., \& Saaty, T. L. (1980). Marketing applications of the analytic hierarchy process. Management science, 26(7), 641-658.

Yalcin, N., Bayrakdaroglu, A., \& Kahraman, C. (2012). Application of Fuzzy Multi-Criteria Decision Making Methods for Financial Performance Evaluation of Turkish Manufacturing İndustries. Expert Systems with Applications, 39(1), 350-364.

Yang, D., Tan, Y., \& Sun, Y. (2009). The Research on The Appraisal of Market Opportunity Based on AHP. J. Service Science \& Management, 2, 276-281.

Yanık, L., \& Eren, T. (2017). Borsa İstanbul'da İşlem Gören Otomotiv İmalat Sektörü Firmalarının Finansal Performanslarının AHP, TOPSIS, ELECTRE ve VIKOR Yöntemleri ile Analizi. Yalova Sosyal Bilimler Dergisi, 7(13), 165-188.

Yücenur, G. N. (2018). Sigorta Sektöründe Kasko Poliçe Seçimi için Bulanık Mantık Temelinde Üç Farklı Çözüm: AHP-ANP-VIKOR Yöntemleri ve Türkiye'den bir Uygulama. Süleyman Demirel 
1447 Işıldak M. S. / Anemon Muş Alparslan Üniversitesi Sosyal Bilimler Dergisi, 2020 8(5) 1435-1446 Üniversitesi Fen Bilimleri Enstitüsü Dergisi, 22(2), 779-793. 